\title{
Líbano uno e diverso: as múltiplas identidades entre imigrantes libaneses no Brasil
}

\author{
André Castanheira Gattaz
}

\section{Introdução}

O texto a seguir apresenta algumas das mais importantes questões surgidas em minha tese de doutorado, História oral da imigração libanesa para o Brasil: 1880-2000. ${ }^{1}$ A pesquisa que a precedeu foi inspirada pelo desconhecimento quase geral quanto à história do Oriente Próximo e à cultura árabe, do qual é resultante a grande confusão semântica no que se refere aos imigrantes levantinos, envolvendo o uso indiscriminado dos termos árabe, turco, sírio, libanês, sírio-libanês, judeu, muçulmano, maometano, entre outros - confusão que eu mesmo, como neto de imigrantes libaneses, bem testemunhei ao longo de minha vida.

Durante a pesquisa procurei conhecer as diversas versões apresentadas sobre o tema, e preocupei-me sobretudo em produzir documentação oral abrangendo os diversos grupos religiosos, regionais e etários representativos dos libaneses no Brasil, o que significou incluir cristãos e muçulmanos - ao contrário de grande parte dos trabalhos historiográficos ou pseudo-historiográficos até então realizados sobre esta nacionalidade, centrados na experiência dos imigrantes cristãos e negligenciando a presença islâmica.

* Doutor em História Social pela Universidade de São Paulo.

1 A tese, apresentada ao Departamento de História da Universidade de São Paulo, foi publicada em formato de livro eletrônico (Gattaz, 2005) e está disponível em www.gandalf.com.br/gattaz.pdf 
Foram entrevistados 28 imigrantes libaneses e descendentes, segundo os critérios da história oral de vida. Para a escolha dos colaboradores, procurei contemplar os principais grupos libaneses no Brasil, definidos quanto a diversos aspectos - sendo os principais o momento da imigração e a prática religiosa. Outros critérios considerados foram a idade e o sexo do entrevistado, sua procedência regional e o seu nível de participação nas atividades da colônia.

Os entrevistados - alçados à posição de colaboradores, uma vez que sem eles esta história oral não teria o formato e a consistência que tem foram instados a narrar sua história de vida, desde a infância até os dias de hoje, contando os fatos que eles consideram mais importantes. Após a entrevista, realizei o processo de textualização, em que as palavras faladas foram adaptadas ao texto escrito através da edição da transcrição literal. Os textos resultantes deste processo foram enviados aos colaboradores, para que o corrigissem e legitimassem, tornando-se então a principal fonte para a análise que empreendi sobre esse processo histórico. ${ }^{2}$

Neste artigo, discuto os aspectos relativos à formação da identidade cultural - ou identidades culturais - dos imigrantes libaneses, num processo que envolveu a criação de uma identidade social baseada no mito do mascate e a manutenção ou rejeição das identidades culturais da região e da religião de origem, através dos laços familiares, da participação (ou não) nos clubes da colônia, e freqüência (ou não) à igreja ou à mesquita.

\section{A criação de uma identidade social: o mito do mascate}

O ofício de mascate foi fundamental na definição da imagem que os brasileiros fazem do grupo imigrante libanês e serviu de instrumental para a ascensão social tanto de cada indivíduo como do próprio grupo. A mascateação tinha as vantagens imediatas de dispensar qualquer habilidade ou soma significativa de recursos, não exigir mais do que o conhecimento rudimentar da língua portuguesa (auxiliado pelo conhecimento prévio do francês), e possibilitar a acumulação de capital em função exclusiva do

2 Detalhei o processo de textualização em "Lapidando a fala bruta" (Gattaz, 1996a), artigo republicado na coletânea Re-introdũindo a História Oral no Brasil, organizada por José Carlos Sebe Bom Meihy (Gattaz, 1996b). 
esforço individual. Depois de poucos anos de mascateação, o capital dos libaneses deslocava-se para o varejo e dali para aplicações no comércio atacadista e sobretudo na indústria, constituindo um setor totalmente integrado verticalmente, em que as industrias e os atacadistas supriam as necessidades de uma rede ampla de varejistas e comerciantes ambulantes pertencentes à mesma etnia (no início deste processo, pouco se distinguiam sírios e libaneses, indistintamente tratados por turcos). ${ }^{3}$

Segundo o estudioso da imigração libanesa Osvaldo Truzzi (1997, p. 53-57), este processo foi sustentado por três fatores (em seu estudo o autor refere-se ao Estado de São Paulo, porém suas reflexões podem ser estendidas ao restante do país):

- perfil singular de distribuição demográfico-ocupacional dos síriolibaneses no país: razoavelmente bem distribuídos entre as diversas regiões do território nacional e, ao mesmo tempo, com alto índice de ocupações urbanas (ver dados adiante);

- relações de complementaridade e mecanismos informais de colaboração estabelecidos no interior da colônia;

- manutenção da célula familiar como modo tradicional de se compreender e se ordenar a vida, associada ao processo de realimentação que representou a importação de parentes e conterrâneos pelos já estabelecidos.

Um dos colaboradores desta pesquisa refere-se à vinda de seu avô um dos que trilharam o caminho de sucesso do mascate na virada do século XIX para o XX:

Marcello: Meu avô [...] veio pro Brasil por volta de 1880, 1890, e se radicou no Rio de Janeiro. [...] Sei que foi um mascate típico, como todos aqueles, e na virada do século ele já estava entre os libaneses ricos do Rio de Janeiro. Deve ter feito muito dinheiro mascateando, e eu sei que por volta de 1910, 1915, ele tinha três lojas.

3 No início do século XX, a Síria era uma província pertencente ao império turco-otomano, e incluía a região denominada Monte Líbano, assim como Beirute. Após a I Guerra Mundial e o esfacelamento do Império Otomano, os interesses neocoloniais franco-britânicos assumiram o controle da região, extraindo da Síria a área que veio a se tornar o Líbano independente. Durante as duas primeiras décadas do século, assim, imigrantes provenientes da Síria (incluindo os de Beirute e Monte Líbano) eram tratados indistintamente por turcos, o que se manteve mesmo após a independência formal (1920) ou efetiva (1942-43) de Líbano e Síria. 
O passo seguinte dado pela colônia foi a penetração dos imigrantes e seus descendentes no mercado de profissões liberais, tornada possível devido ao forte investimento realizado na educação própria ou dos filhos - como se nota nos depoimentos dos colaboradores desta pesquisa. Isso fez com que os libaneses tivessem uma ainda melhor apreciação social entre a elite das grandes cidades, assumindo já nos anos 1950 a direção de importantes associações classistas e órgãos estatais e entrando com bastante ímpeto para a política parlamentar e logo executiva - fato do qual os chamados intelectuais da colônia bastante se orgulham em seus panegíricos.

Dados do recenseamento de 1950 indicam que apesar de os sírios e libaneses formarem tão somente o oitavo grupo estrangeiro então presente no Brasil, passam à quarta posição quando se consideraram os sócios das empresas individuais e sociedades brasileiras à época, ficando atrás apenas de portugueses, italianos e espanhóis. Tomando-se a proporção de empresários sobre o total de imigrantes da etnia, os sírio-libaneses passam à primeira colocação, com índices de duas a três vezes superiores aos dos demais grupos (dados do Censo de 1950, disponíveis em Diégues Jr., 1964).

Outro dado importante extraído do mesmo recenseamento indica que os sírios e libaneses, entre os oito principais grupos imigrantes, são aqueles que apresentam a maior distribuição entre as cinco regiões do Brasil - o que justifica a comum expressão: "Em toda cidade do Brasil tem uma lojinha de turco". Enquanto as sete principais etnias concentravam, em 1950, entre 96,7\% e 98,9\% de seus imigrantes nas regiões Leste e Sul ${ }^{4}$ - para onde se dirigira o grosso da imigração -, entre os sírios e libaneses este número era de apenas $91,4 \%$. Por outro lado, nas regiões Norte, Centro-Oeste e Nordeste os sírios e libaneses apresentavam-se como o grupo com a maior porcentagem relativa de imigrantes. Em números absolutos, a etnia sírio-libanesa ficava em segundo lugar na região Norte e em primeiro lugar na região Centro-Oeste.

A ascensão social não foi porém regra única e invariável para os libaneses. Muitos imigrantes, ainda que vindos ao Brasil nas primeiras décadas do século, só conseguiram atingir o patamar de pequenos comerciantes, nunca alcançando a ambicionada fase de atacadista ou industrial. Outros nem a isso chegaram, permanecendo como funcionários de seus parentes

4 À época, a região Leste incluía RJ, ES e MG; enquanto a região Sul incluía SP, PR, SC e RS. 
mais bem estabelecidos. Há ainda alguns poucos relatos de libaneses trabalhando em fazendas ou como sitiantes, especialmente como cafeicultores nos estados de São Paulo e Minas Gerais, mas mesmo esta parece ter sido uma opção pouco viável entre os libaneses devido à diferença da estrutura agrária entre os dois países e a falta de capital para investir em terras. Tais casos são raramente citados pelos intelectuais da colônia ou mesmo por parte dos historiadores de ofício, eles mesmos envolvidos pelo mito do mascate, porém são evidentes na observação da colônia ou nas conversas e entrevistas com os imigrantes.

Houve ainda casos especiais daqueles imigrantes que já encontraram uma estrutura de apoio montada e puderam dispensar o ofício de mascate, entrando diretamente no comércio ou mesmo no mercado de profissões liberais por meio da obtenção de um grau universitário - é o caso de Samer, que trabalhou como comerciante para poder pagar sua formação universitária:

Eu comecei a fazer o supletivo, com a idéia de terminar o Colegial, fazer a Faculdade e começar a ganhar dinheiro pra poder ajudar minha família no Líbano. Eu estudava sempre à noite, para poder trabalhar de dia. Vendi o apartamento que o meu tio Raja tinha deixado pra mim quando ele faleceu e abri uma loja lá no Brás. Comecei a trabalhar, a ganhar dinheiro e pude ajudar minha família - eu sentia que eu estava em dia com eles: eles estavam precisando, eu estava trabalhando e podia ajudar. Ao mesmo tempo, a situação dos meus irmãos já foi melhorando, então quando eu fechei a loja eles já estavam bem, já estavam sossegados, então eu pude entrar na Faculdade de Arquitetura e começar a fazer estágios ganhando pouco.

Não obstante as exceções, parece fora de dúvida que até os anos 1950 era comum para os imigrantes libaneses, nos primeiros anos de trabalho no Brasil, a escolha de ofícios como a mascateação ou o trabalho em lojas ou restaurantes.

Se nas primeiras fases da imigração estas ocupações permitiam a acumulação de capital para a abertura de um negócio próprio e o financiamento dos estudos dos filhos, após os anos 1950 os imigrantes passaram a concentrar seus esforços no binômio trabalho-estudo, pois sentiam que 
não era mais possível a rápida ascensão econômica permitida aos primeiros imigrantes através apenas da atividade comercial (o que lhes permitia prover a seus filhos a oportunidade de estudos em faculdades e cursos tradicionais).

É com bastante freqüência, assim, que se vê entre os libaneses chegados após a década de 1950 a preocupação com a formação profissional correndo paralela à manutenção material - como atestam vários depoimentos desta pesquisa, revelando casos mais ou menos bem sucedidos de escalada econômica e social.

Mustafa: Comecei a pegar mercadoria da loja [do meu parente] e fui vender nos bairros da periferia, onde Judas perdeu o sapato! Santa Clara, Vila Diva, Vila Formosa, Vila Alpina; a maioria das ruas era de terra, não tinha nem asfalto. Então fui mascateando: um dia vende, outro não vende; uma freguesa paga, outra não paga... [...] [Em 1955] começamos a trabalhar os três sócios na loja de tecidos, cama, mesa e banho.

Ahmed: Aos 14 anos, meu pai me deu uma banca na loja dele e disse: "Essa banca é pra você começar a trabalhar". Começamos a trabalhar, vendendo três pares de meia por um cruzeiro, e de lá pra cá nós fomos nos dedicando ao trabalho e conseguindo alguma coisa [...]. Depois eu me formei em Economia [...], só que acabei voltando às origens, abrindo uma loja de roupa infantil.

Murched: Chegando aqui, eu comecei a trabalhar cedo, e a estudar. Tinha que sustentar minha mãe e minha irmã, e comecei a trabalhar desde pequeno. Fui trabalhando, trabalhando, fiz de tudo um pouco, mas sempre vendendo roupa. [...] Eu também tinha uma banca de laranja na feira aos sábados e domingos e à noite vendia bala na Penha. [...] Aí, eu fui estudar no interior, e custeei toda a minha manutenção na escola vendendo roupa, até praticamente o último ano de faculdade. Quando me formei, comecei a trabalhar de médico e larguei a atividade comercial. Depois que eu me formei, fiz residência médica durante quatro anos, fiz um estágio de seis meses na Inglaterra, e fiz o Mestrado e o Doutorado na Universidade Federal de São Paulo. 
Entre os imigrantes muçulmanos, cuja imigração é mais recente, o padrão da mascateação como forma de obter o capital para o estudo ou o crescimento comercial manteve-se predominante pelo menos até a década de 1960, sendo que ainda nos anos 1980 encontram-se imigrantes trabalhando como mascates na região da Grande São Paulo:

Jihad: Aqui em São Bernardo, eu estudava na parte da manhã, às vezes na parte da tarde, e o tempo livre eu mascateava com meu pai. Ele me deixava num lugar e ia pra outro. Eu com onze anos, doze anos, já carregava aquelas sacolas de lona!

Emad: Como eu estava louco pra vender de qualquer jeito, eu ia pra qualquer lugar, mas me concentrei na zona leste. Pegava o ônibus com a sacola nas costas e tchau!

Não é à toa que o mascate firmou-se no imaginário popular como o estereótipo do imigrante sírio-libanês (conhecido vulgarmente como turco de prestação), carregando ao mesmo tempo atributos positivos como perseverança, coragem e honestidade, e negativos, como oportunismo suspeito, o fato de muitos serem "maometanos" e a desonestidade (amplificada através de mitos como o do turco que bate com o metro no chão para encurtá-lo). Pode-se dizer, porém, que em geral a apreciação nacional do imigrante árabe, até os anos 1930, foi mais negativa do que positiva.

Em resposta a esta idéia que se formava na sociedade brasileira sobre os turcos, a colônia sírio-libanesa desenvolveu uma estratégia que envolvia não a anulação, mas a aceitação da identidade que lhe era atribuida pelos nacionais, agora transformada e recoberta com vernizes positivos - afinal, como notou Truzzi (1997, p. 76): "a figura do mascate constituiu a única base possível de identidade coletiva de uma colônia fragmentada entre diversas religiões e regiões de origem".

Formou-se assim um mito abraçado pelos intelectuais da colônia poetas, jornalistas e escritores que trataram de dar um corpo "teórico" à imigração libanesa. Estes escritores destacavam a coragem, a perseverança, a frugalidade e a honestidade dos mascates pioneiros, e a sua dedicação ao trabalho, à família e à religião (cristã ou islâmica) - enquanto as histórias que assustavam os brasileiros eram reduzidas a inverdades ou casos isolados. Verdadeiras epopéias foram escritas, como o poema 
O Mascate, de Assis Feres (apud Safady, 1966, p. 185), que narra em mais de 700 versos a história de seu pai, mascate roubado e assassinado - embora, segundo o próprio autor, o poema seja insuficiente para expressar toda a coragem e honestidade do mascate:

Descrever os pormenores / de todo o espírito da luta, /

Da inemolgável figura / Do ser esta apologia, / Então, preciso seria / Recorrer a várias plumas / De juízes e servos de ofícios / Da geologia dos textos.

Não apenas a poesia, mas também os textos de caráter histórico adotaram o mascate como mito fundador da colônia, construindo sobre ele a caracterização de toda uma etnia, como indica o exemplo a seguir:

O mascate percorreu o Brasil inteiro de lado a lado alicerçando com seu esforço a base do trabalho dos ben-árabes estabelecidos de hoje. O mascate implantou com sua coragem e honestidade, em todos os cantos desta terra abençoada por onde passou, uma muda de amor ao trabalho fecundo e uma semente sagrada de família honrada e modesta. [...] O mascate se fixara transformando-se no forte comerciante ou no industrial progressista que não encontrou obstáculos para deter sua gigantesca evolução e sólida penetração em todos os setores da economia brasileira, cujo capítulo deverá ser escrito com letras de ouro como tentativa de equiparação com o suor e sangue dispendidos pelos vanguardeiros (Safady, J. 1994, p. 60).

Os colaboradores desta pesquisa referem-se também ao mascate, e fica claro que enquanto os mais idosos ou mais atuantes na colônia mantêm o mesmo tom das epopéias dos intelectuais, os mais novos relativizam ou ironizam o sucesso da mascateação, notando que nem todos conseguiram traçar o percurso de um Jafet ou Calfat. No primeiro caso encontra-se o Sr. Farid, nascido em 1920 e residente no Brasil desde 1936, que relata:

Os libaneses prosperaram em seu comércio de tecidos e armarinhos e fizeram da Rua 25 de Março, em São Paulo, o centro 
irradiador a todo Brasil dessas mercadorias. E em seguida, se propuseram a fabricar as mercadorias de seu próprio comércio, entrando na indústria têxtil, o que logo eliminou a importação desses produtos. Em seguida, abraçaram outras indústrias: confecções, calçados, plásticos, armarinhos, siderurgia e fundição, autopeças, máquinas, bancos, seguros e outras, além da atividade imobiliária e de construção, que na mão deles se tornou pujante e poderosa.

No segundo caso, encontra-se a professora Safa, nascida em 1962 e residente no Brasil desde 1982, para quem o sucesso econômico e social da colônia não pode ser negado, porém tampouco pode ser generalizado, pois não foram todos os imigrantes que conseguiram a ascensão econômica pintada com cores tão vivas pelos intelectuais da colônia:

Então dá para caracterizar vários tipos de imigração, mas agora você não tem mais o mascate. $\mathrm{O}$ cara vem, mesmo com pouco dinheiro já vai ter alguém aqui para acolhê-lo. Esse meu tio que veio para cá, trabalhou a vida inteira até a hora de morrer! [...] Essas riquezas, esses impérios que foram feitos, foi um momento, acabou mesmo! [...] Claro, acabou ficando aquela lenda, aquela mitologia...

O relativo sucesso econômico e a conseqüente ascensão social dos libaneses provocaram uma mudança na imagem que o brasileiro fazia do mascate e do comerciante árabe na sociedade. Ao passo que nas primeiras décadas do século XX os estereótipos negativos predominavam, com o tempo os "turcos" começaram a ser visto com mais respeito, sendo destacadas suas características positivas. O comércio serviu, assim, à manutenção material do próprio imigrante e da família, à sua inserção na sociedade e especialmente na elite brasileira através da ascensão econômica, e à formação das imagens interna e externa da colônia, em que se destacam o talento comercial e o senso de oportunidade do libanês.

A fim de facilitar sua integração à sociedade local, os imigrantes libaneses reelaboraram os estereótipos correntes sobre a etnia visando excluir os aspectos negativos e reforçar os positivos, numa tentativa de forjar uma nova identidade que fosse compatível com a tolerância étnica brasileira. 
Essa nova identidade, ademais, formava-se naturalmente com a adoção da língua portuguesa e assimilação da cultura e dos hábitos locais - uma identidade mais brasileira do que libanesa.

\section{A manutenção das múltiplas identidades culturais}

Ao mesmo tempo em que procuravam integrar-se à sociedade local, os imigrantes libaneses sentiram a necessidade de estabelecer formas de manutenção de suas tradições culturais e de sua identidade étnica definida nos níveis particulares da cidade de origem, da religião e da familia, e não em torno de uma idéia de nação libanesa, como apontam dois entrevistados:

Jorge: Você pergunta hoje: "O Sr. de onde é?" Ele não fala libanês, fala: "Sou zahliota." O outro fala: "Sou beirutino"... Mas nós somos todos libaneses!

Ibrahim: Se você vai no Vale de Bekaa, quando você conversa de alguém da região, a primeira pergunta que você faz é: "De que cidade você é?" e "Qual é a sua família?". É uma forma de você identificar a pessoa, já que o árabe, o libanês no caso, ele se identifica muito com a família. Se quer conhecer alguém, tem que conhecer a origem dele, o sobrenome dele.

Os libaneses encontraram, assim, na família, nos clubes regionais e nas igrejas e mesquitas os espaços de sociabilização em que suas tradições podiam ser mantidas sem o receio do olhar preconceituoso do cidadão brasileiro.

O primeiro espaço da sociabilização encontra-se no nível da família, envolvendo a própria família, a parentela e os amigos - em geral oriundos da mesma cidade ou aldeia libanesa, e que nas grandes cidades do Brasil vieram a concentrar-se em determinadas ruas ou bairros, como as imediações da 25 de Março em São Paulo e da Rua da Alfândega no Rio de Janeiro. No espaço familiar mantinham-se (e mantêm-se) as tradições tanto da ampla cultura árabe (culinária, língua, história), como dos grupos religiosos ou locais particulares (ritos religiosos, tradições locais, variantes 
da língua e da culinária etc.) - conforme narraram diversos colaboradores da pesquisa:

Marcello: $\mathrm{O}$ meu nascimento deve ter sido um exemplo típico do nascimento do filho de um imigrante libanês: [...] era uma festa aquilo! Fumando, bebendo, jogando baralho, contando histórias, cantando... Enfim, tentando trazer para aquele pedacinho, praquela salinha da Rua Stela, aquela sensação de que eles estavam nas montanhas do Líbano. [...] A casa do libanês era solo santo para ele, era solo libanês, então ele mantinha todos aqueles costumes.

Danilo: A família em nenhum momento se distanciou da cultura árabe: o que tinha lá, passou a ter aqui. Sempre foi falado árabe em casa, mantivemos as nossas festas, a cultura, a comida; toda hora estamos falando do Líbano, mantendo contato.

Lody: Este meu amor ao Líbano, esta vontade de defender a causa do Líbano, devo muito a meu pai, porque ele sempre falava do Líbano em casa. Ele também participava muito da colônia e da Igreja - onde tinha alguma festa, algum evento, ele estava.

Entre os imigrantes muçulmanos, além da preservação de tradições culturais, nota-se no espaço familiar uma forte preocupação com a manutenção da identidade religiosa. Parte destes imigrantes, assim, esforçase seriamente para transmitir a religião aos filhos, pois percebe que se não o fizer, o entorno cristão os levará a abandonar o islamismo - o que vem ocorrendo com os filhos daqueles que negligenciaram a educação islâmica, como notam alguns imigrantes muçulmanos:

Jihad: Algumas famílias caminham para o abandono do islamismo - essa é a realidade; eu não posso tapar o sol com a peneira. [...] A pessoa que cresce dentro de uma família islâmica, vê os pais rezando etc., mas não adquire esse conhecimento profundo, vai se afastando aos poucos da religião dele. [...] É um vazio que precisa ser preenchido, e passa a ser preenchido com a escola, com os amigos, porque não the foi dado base, quando ele era pequeno, pra poder sustentá-lo na adolescência e na fase adulta. 


\begin{abstract}
Ahmed: É necessário passar as tradições aos filhos - hoje, o pai que não passa as suas tradições, seus costumes, não preserva para o futuro. Se você nasceu num berço cristão, você vai crescer naquele berço, mas vai depender dos seus pais de passar ou não os costumes, os ensinamentos. Se você não passar, ele vai captar do meio em que ele vive! Se você passar, depois ele vai saber captar entre o dele e o que existe no mercado, ele classifica o que é melhor pra ele!
\end{abstract}

Nesse sentido, em relação aos imigrantes cristãos, a família muçulmana tem maior importância na preservação das identidades culturais, pois além de encontrarem menor oferta de locais de sociabilização, os muçulmanos enfrentam o problema de praticar uma religião quase inexistente no país e cercada de muito preconceito, fazendo com que a família torne-se o fator mais importante na preservação da identidade.

Nota-se ainda que, ao contrário dos cristãos libaneses, a formulação da identidade do grupo não se dá em função da região e seita de origem, porém em torno do islamismo como religião universal (assim, em vez de maronita do Monte Líbano, melquita de Zable ou ortodoxo de Marjayoun, o muçulmano afirma-se simplesmente como muçulmano ou árabe).

O segundo importante espaço de sociabilização da colônia libanesa foram as associações sócio-culturais e esportivas que desde o início do século vêm sendo criadas onde quer que os libaneses tenham se estabelecido. Estas associações - ou simplesmente clubes - foram fundamentais para a manutenção de uma identidade étnica árabe-libanesa, embora na maioria das vezes filtrada pelo viés da origem regional.

A fundação dos clubes libaneses nas primeiras décadas do século XX deu-se em função da necessidade de locais de sociabilização devido à pouca presença da família no cotidiano do imigrante libanês - uma vez que à época, a maioria dos imigrantes eram homens solteiros. Além disso, no ambiente do clube permaneciam hábitos sociais que mesmo na família se perderiam - pois era no clube que se dava a verdadeira sociabilidade entre os membros da colônia, envolvendo hábitos culturais, uso da língua árabe, posicionamentos políticos e sectários, estratégias de união patrimonial através de casamentos e alianças, competição individual e grupal (nos níveis político, social e esportivo) etc. 
A formação dos clubes, especialmente nas grandes capitais, esteve condicionada por uma característica marcante dos imigrantes cristãos libaneses no Brasil: sua extrema fragmentação em grupos delimitados pela origem regional, mais notável quanto maior a participação do indivíduo nas associações da colônia e sua melhor posição sócio-econômica. Este culto à região de origem, portanto - e não à nação libanesa em si - foi a tônica para a formação das associações sócio-culturais e esportivas libanesas que representam as dezenas de regiões de origem. Diz a Sra. Najla, nascida em 1913 e residente no Brasil desde 1928:

Primeiro não tinha clubes aqui. Daí fizeram o Zahle Clube, depois fundaram o Homs, depois foi o Monte Líbano, e o pessoal de cada cidade não quer deixar por menos, quer um clube da cidade dele: tem Marjayoun, tem Rashaya, tem Homs, tem Alepo, cada um faz um clube, mas são todos unidos.

Apesar de criticado por muitos, este excessivo particularismo continua vigorando até hoje, quando nas principais capitais subsistem vários clubes regionais, apesar da cada vez menor afluência de sócios e participantes - enquanto a existência de menos associações, porém mais genéricas e efetivas, poderia trazer melhores frutos, como nota hiperbolicamente o Sr. Jorge (nascido em Beirute em 1919, e residente no Brasil desde 1951):

O libanês, infelizmente, não tem união, isso eu posso dizer. Precisamos da união, mas somos todos divididos. Aqui tem CINQUENTA clubes! Eu já sugeri em uma carta, quando George Germanos era presidente, de reunir todos e fazer o Monte Líbano, com um prédio em cada região: um prédio pra esporte, outro pra jogos, outro pra literatura... Agora: nós temos: Zahle Clube, Rashaya Clube, Marjayoun, Monte Líbano, drusos também... Tem um clube no interior que eu encontrei, que tem cinco membros só! Formaram um clube!

Ao se analisar as associações fundadas nas primeiras décadas do século passado, nota-se que enquanto os cristãos, especialmente libaneses, procuravam estabelecer-se em clubes regionais, os muçulmanos procuraram 
criar entidades mais abrangentes. Nota-se também que, quando existentes, as associações de caráter nacional ou transnacional (quando não religiosas) filiavam-se aos programas políticos nacionalistas sírio ou trans-árabe, e foram forçadas a encerrar suas atividades com as leis restritivas de 1934 e 1938. Ao extremo particularismo libanês, assim, juntaram-se questões políticas entre sírios e libaneses, que vieram a dificultar a formação de entidades transnacionais de caráter árabe e sírio-libanês.

É notável o fato de que em São Paulo os dois maiores clubes da colônia denominem-se, respectivamente, Esporte Clube Sírio e Clube Atlético Monte Líbano, indicando a profunda cisão entre as elites das duas nacionalidades à época de sua fundação - uma vez que na prática os dois clubes, especialmente o primeiro, são atualmente freqüentados por sírios e por libaneses. É também significativo que estes clubes, os únicos a sobreviverem como importantes clubes da capital, tenham se firmado com base na prática do esporte e na valorização da ampla cultura árabe, atenuando seus aspectos regionais ou nacionalistas, embora os nomes assim o sugiram. Isto fez com que ao longo dos anos esses clubes tenham continuado a atrair os imigrantes e seus descendentes - estes não mais preocupados com a manutenção de uma identidade étnica, porém com a simples prática esportiva e convivência social.

Em resumo, tem-se o seguinte posicionamento dos setores da colônia sírio-libanesa quanto às associações:

- para os cristãos libaneses, a preocupação maior foi com a preservação de tradições que, embora árabes, eram filtradas pela cidade de origem; para os cristãos provenientes do Monte Líbano, especialmente, houve a preocupação com a criação de instituições que defendessem a "cultura libanesa", em oposição à cultura árabe. As linhas demarcatórias da identidade desse grupo, assim, tornaramse a prática religiosa e a origem local.

- para os sírios e parte dos libaneses (especialmente os cristãos ortodoxos e muculmanos do sul do Líbano), a tônica era a defesa do nacionalismo sírio ou trans-árabe - refletindo na criação de associações patrióticas sírias ou árabes em quase todas as cidades onde a colônia estava presente, das quais poucas subsistem. Essas pessoas definem-se em geral como sírios, mesmo tendo nascido no Líbano - lembra-se que até 1920 o Líbano não existia enquanto país, sendo apenas uma 
região montanhosa da província da Síria; aqueles que nasceram fora da área do Monte Líbano, portanto, têm uma relação identitária muito mais forte com a cultura árabe (islâmica ou cristã) do que com a cultura cristã-mediterrânea do Monte Líbano.

- para os muculmanos (libaneses, sírios e outros), a manutenção das tradições culturais e a sociabilização deram-se em torno da religião, levando ao estabelecimento das mesquitas e associações beneficentes muçulmanas, onde não se considera a origem nacional de seus participantes como um fator importante. A formulação da identidade dos pertencentes a este grupo, portanto, não passa pela origem local ou nacional, definindo-se pela ligação mais profunda com a ampla cultura árabe e islâmica.

Nota-se que ao passo que as entidades e federações libanesas, sírias e árabes muitas vezes percam-se na discussão sobre se o Líbano pertence ou não ao mundo árabe, efetivamente realizando poucas ações concretas quanto à vida dos imigrantes, suas congêneres muçulmanas têm uma atividade mais prática, voltada à assistência aos necessitados e à construção de novas mesquitas e instituições beneficentes. Pesa para isso o fato de que os muçulmanos constituem o principal grupo imigrante libanês que chegou ao Brasil na segunda metade do século XX, enquanto o grosso da imigração cristã é referente aos anos 1900-1930, o que faz com que suas entidades percam paulatinamente a importância com o falecimento dos mais velhos e desinteresse dos mais jovens.

É importante notar ainda que a manutenção da identidade étnica através da participação nas entidades da colônia não se mostrou como regra para todos os imigrantes libaneses, pois muitos não apenas deixaram de se aproximar, como realmente procuraram um afastamento da colônia e suas instituições. Este movimento foi empreendido especialmente por jovens que procuraram a ascensão social e econômica através de profissões qualificadas que exigem a convivência com cidadãos brasileiros. Para estas pessoas, que teriam de reconstruir suas vidas no Brasil a partir da juventude, a integração à sociedade local no menor tempo possível era uma necessidade, e neste sentido a convivência dentro da colônia foi vista como um obstáculo a ser evitado - como notam alguns dos mais jovens colaboradores da pesquisa: 
Safa: Outra coisa que me ajudou foi que eu não fiquei muito na comunidade - isso ajudou demais! Os amigos do meu marido acabaram sendo os meus amigos, então sempre falavam português e isso ajudou.[...] No início, quando eu tinha acabado de casar, quase no início da minha vida aqui, a única coisa que eu tinha pra fazer era ir na casa da minha irmã. [...] Mas chegou um ponto que eu já não gostava desse tipo de coisa, não via que saísse nada disso, então quando eu comecei a estudar, nunca mais voltei.

Simon: Nós mantemos contato com o Líbano, mas nossa vida está aqui. Estamos satisfeitos, somos naturalizados, também nos consideramos brasileiros, então a nossa vida no Brasil é como brasileiros.

Além da casa familiar e dos clubes regionais, a igreja e a mesquita (com suas respectivas instituições beneficentes e culturais) foram mais um espaço importante de sociabilização e manutenção das identidades da comunidade libanesa. A peculiaridade da relação entre a colônia e as religiões é que, devido ao mosaico religioso de que se constitui o Líbano e uma vez que poucos libaneses professavam o catolicismo ao chegar ao Brasil, valorizou-se a relação específica com determinada seita e igreja, levando à formação de grupos religiosos distintos e por vezes conflitantes.

Este excessivo particularismo religioso dividindo uma colônia relativamente pequena (se comparada aos grupos português, espanhol e italiano no Brasil, por exemplo), e a intensa e complicada associação entre religião e política no Líbano, fez com que se criassem barreiras à convivência entre praticantes de religiões diversas. Isto se nota ao se perguntar aos colaboradores sobre a relação entre os praticantes dos diversos ritos no Brasil - desaparecendo a unanimidade que se encontra quando o assunto é a convivência inter-religiosa no Líbano.

Quando se referem à convivência entre as seitas religiosas no Líbano, os entrevistados sistematicamente afirmam que todos os grupos sempre conviveram pacificamente, e que apenas após 1975, com a interferência de potências estrangeiras, o quadro mudou. As opiniões chegam a ser semelhantes inclusive na forma, e alguns aspectos, como as visitas realizadas a amigos praticantes de outras seitas por ocasião de suas festas 
religiosas, são mencionados por quase todos os imigrantes que vieram para o Brasil entre as décadas de 1920 e 1950.

Samira: Na nossa cidade, éramos como irmãos entre as religiões diferentes! Lá tem muito católico, ortodoxo, presbiteriano, druso [...]. Toda a vida a convivência foi como uma família só.

Mustafa: Toda a vida vivemos muito bem no Líbano: muçulmanos, católicos, maronitas, ortodoxos... Não tinha coisa nenhuma!

No relato dos mais jovens, porém, que viveram os graves tempos de guerra no Líbano, nota-se como a convivência entre os praticantes de diversas religiões começou a se tornar difícil em função dos conflitos:

Geraldo: Antes da guerra, a convivência não tinha absolutamente nada de errado. Inclusive no bairro onde eu vivia, principalmente na nossa rua, a maioria era de muçulmanos, e a convivência com eles era normal, eles participavam das nossas festas, a gente participava das festas deles... Não tinha nenhuma diferença, era como se fosse uma família só.

Simon: A convivência entre as religiões em Beirute para nós era normal. Nós pessoalmente não tínhamos problemas de religião com ninguém, até hoje não temos problema de religião. Sempre existiu uma convivência entre as religiões no Libano, até hoje existe. Essa convivência só se perturbou nos momentos de guerra, nos momentos de crises, nas interferências estrangeiras.

Safa: Eu tinha colegas muçulmanos, sunitas, xiitas, isso nunca foi um problema - até estourar a guerra. Com a guerra vêm à tona coisas antigas, e fica mais difícil. Quando você está no meio, começa a ficar envolvido, você não tem como fugir, então você acaba indo para um lado...

Já no que se refere às relações inter-religiosas no Brasil, as opiniões chegam a ser contraditórias, e enquanto alguns afirmam que a convivência é pacífica, outros realçam os conflitos presentes entre os grupos. 
Uma análise mais detalhada deixa claro que à medida que aumenta o grau de envolvimento do imigrante com as entidades da colônia, maior é a percepção dos problemas entre os grupos - não só entre os grupos religiosos, mas também entre sírios e libaneses. No extremo inferior da pirâmide referente à atividade na colônia, representado por aqueles que não têm participação efetiva nas entidades religiosas, políticas ou sócioculturais líbano-brasileiras e que se integraram plenamente à vida brasileira, comprova-se que geralmente a convivência inter-religiosa existe em termos positivos. Estas pessoas costumam manter relações efetivas e cordiais com imigrantes de outras origens, e não raro ocorrem casamentos entre pessoas de ritos distintos (unindo inclusive cristãos a muçulmanos). Curiosamente, este aspecto positivo da convivência inter-religiosa libanesa é destacado principalmente pelos colaboradores muçulmanos.

Mustafa: A religião é de Deus. Todas elas são boas: católico, protestante, muçulmano; nenhuma religião manda fazer o mal ou ter inveja do outro e falar mal da outra religião. [...] Lá em baixo tenho vizinhos ortodoxos, católicos, maronitas, e eu graças a Deus vivo muito bem com eles, como se fossem parentes. Também tenho vizinhos brasileiros e nunca tive nada de encrenca com eles nesses 41 anos que eu moro aqui. Quando passo na porta todos me cumprimentam: 'Ô Mustafa, como vai??

Murched: Sou casado com uma cristã libanesa e vivemos pacificamente bem, não há nenhum conflito em casa.

Omar: Eu convivi muito lá na 25 de Março com essa gente. E não havia conflito religioso - mesmo até entre árabes e judeus, não há esse conflito que há lá no Oriente Médio. Aqui eles convivem, na 25 de Março, na rua mesmo, é normal! Cada um tinha a sua crença religiosa, respeitava a crença do outro e tocava a vida! [...] Por exemplo o Marcello se casou com a filha de um islamita, o Said Mustaphá Hamud, que tinha o Alcorão na cabeceira da cama, mas que foi criada no catolicismo...

Esta convivência, no entanto, não ocorre em todos os setores da comunidade, pois à medida que se torna mais intensa a participação do 
imigrante nas entidades da colônia, ou mais recente a imigração do indivíduo entrevistado, surgem afirmações que negam a integração vista acima, ou práticas que não equivale ao discurso da total integração. Sobre este aspecto, percebemos em algumas entrevistas realizadas e na observação da comunidade libanesa que muitos líderes das entidades da colônia, embora afirmem que não têm preconceito ou restrições aos imigrantes de outras crenças religiosas, não demonstram isto na prática, vivendo isolados dos demais grupos. Essa intolerância é especialmente mais intensa quando a relação opõe cristãos, principalmente maronitas, a muçulmanos, especialmente xiitas, sendo suavizada quando se tratam de melquitas ou ortodoxos em relação aos muçulmanos.

A análise ampla deste assunto, para felicidade dos libaneses de espírito verdadeiramente ecumênico, parece mostrar que as diferenciações vão diminuindo, especialmente entre as pessoas comuns e de pouca participação política na colônia - a despeito das resistências opostas por certos líderes da comunidade e por alguns imigrantes mais recentes que trazem ainda abertas as feridas da guerra. Espera-se que, a exemplo do que ocorreu em outros países, o passado torne-se realmente passado, e os mortos da guerra deixem de atormentar a vida dos sobreviventes.

\section{Referências Bibliográficas}

DIÉGUES JR., MANUEL. Imigração, Urbanização e Industrialização. Rio de Janeiro: Instituto Nacional de Estudos Pedagógicos, 1964.

GATTAZ, A.C. Braços da Resistência: uma história oral da imigração espanhola. São Paulo: Ed. Xamã, 1996 (a).

. Lapidando a fala bruta: a textualização em história oral. In: MEIHY, J.C.S.B. (Org.) (Re)definindo a História Oral no Brasil. São Paulo: Ed. Xamã, 1996 (b), p. 135-40.

Do Líbano ao Brasil: História oral de imigrantes. São Paulo: Gandalf, 2005. Disponível em: www.gandalf.com.br/gattaz.pdf.

ISSAWI, CHARLES. The Historical Background of Lebanese Emigration, 1800-1914. In: HOURANI, A.; SHEHADI, N. (Ed.). The lebanese in the World: a Century of Emigration. London: The Centre for Lebanese Studies / Tauris \& Co, 1992, p. 13-31.

KNOWLTON, CLARK S. The Social and Spacial Mobility of the Syrian and Lebanese Community in São Paulo, Brasil. In: HOURANI, A.; SHEHADI, N. (Ed.). The lebanese in the World: a Century of Emigration. London: The Centre for Lebanese Studies / Tauris \& Co, 1992, p. 285-311. 
RABINOVICH, ITAMAR. (b). The war for Lebanon, 1970-1985. Ithaca/London: Cornell University Press, 1985.

SAFADY, JORGE. A imigração árabe no Brasil: 1880-1970. São Paulo: Ed. Garatuja, 1994 (1a ed. 1972).

SAFADY, WADIH. Cenas e cenários dos caminhos de minha vida. Contribuição para o Estudo da imigração árabe no Brasil. Belo Horizonte: 1966.

TRUZZI, OSWALDO De Mascates a Doutores: sírios e libaneses em São Paulo. São Paulo: Ed. Sumaré, 1992.

. Patrícios: sírios e libaneses em São Paulo. São Paulo: Hucitec, 1997.

Resumo: $\mathrm{O}$ artigo apresenta um panorama das múltiplas identidades abraçadas pelos imigrantes libaneses no Brasil, num conflito sutil opondo a busca de uma identidade nacional versus as diversas identidades locais e religiosas, que se mantêm no país de adoção. Inicialmente discute-se o conhecido "mito do mascate", tentativa de atribuir unidade cultural e valorizar os atributos sociais dos imigrantes libaneses - e que por vezes ocultou a existência de setores menos privilegiados entre estes. Notam-se, em seguida, as diferenciações entre os diversos grupos que constituem a colônia de imigrantes libaneses e seus descendentes, no que se refere aos aspectos principais para a identificação social e cultural de cada indivíduo e cada grupo: a origem local e a prática religiosa.

Palavras-chave: imigração libanesa; identidade cultural; história oral.

Multiple identities among Lebanese immigrants in Brazil

Abstract: This article presents a panorama of the multiple identities assumed by Lebanese immigrants in Brazil, in a subtle conflict opposing the search for a national identity versus the several local and religious identities maintained in the country adopted. Initially it discusses the well-known "myth of the peddler," an attempt to confer cultural unity and to value the social attributes from Lebanese immigrants - and that many times has obliterated the existence of less privileged sectors among them. Then are described the differentiations among the several groups that constitute the colony of Lebanese immigrants, and their descendants, concerning the main aspects related to the social and cultural identification of each individual and each group: the local origin and the religious practice.

Keywords: Lebanese immigrants in Brazil; cultural identity; oral history. 